\title{
Effect of extraction method on activities of polysaccharide-depolymerase enzymes in the microbial population from the solid phase in the rumen
}

\author{
P Nozière, B Michalet-Doreau *
}

\begin{abstract}
INRA-Theix, Station de Recherche sur la Nutrition des Herbivores, Unité de la Valeur Alimentaire, 63122 Saint-Genès-Champanelle, France
\end{abstract}

(Received 15 November 1993; accepted 14 March 1994)

\begin{abstract}
Summary - Samples of rumen digesta were collected from 2 cows fed with a 100:0 or 40:60 forage/concentrate diet $1 \mathrm{~h}$ before and $2 \mathrm{~h}$ after feeding. Enzymes from particle-associated microorganisms were extracted by 5 different methods, including physical (freezing, grinding and sonication) or chemical and enzymatic (autolysis in a buffer, lysozyme and $\mathrm{CCl}_{4}$ ) treatments. Hydrolytic enzyme activities were measured on 3 polysaccharidic substrates: xylan, carboxymethylcellulose and Avicel cellulose. Contamination of enzyme preparations by feed proteins was evaluated. For the 3 substrates, the effect of feeding (sampling time and diet) on enzyme activities was independent of extraction method. Maximal activities were obtained with treatments including lysozyme and $\mathrm{CCl}_{4}$ or grinding in liquid nitrogen. Contamination of enzyme preparations by feed proteins was higher with chemical and enzymatic methods than with physical treatments.
\end{abstract}

rumen / particle-associated microorganism / enzyme activity / polysaccharidedepolymerase

Résumé - Effet de la méthode d'extraction sur l'activité des polysaccharidases de la population microbienne de la phase solide dans le rumen. Des échantillons de contenu ruminal ont été prélevés $1 \mathrm{~h}$ avant et $2 \mathrm{~h}$ après le repas, sur 2 vaches recevant soit une ration à base de foin, soit une ration à base de foin et d'orge dans les proportions 40:60. Les enzymes de la population microbienne adhérente à la phase solide ont été extraites par 5 méthodes différentes faisant intervenir des traitements physiques (congélation, broyage, sonication) ou chimiques et enzymatiques (autolyse dans un tampon, lysozyme et $\mathrm{CCl}_{4}$ ). L'activité hydrolytique des enzymes a été mesurée sur 3 substrats polysaccharidiques : le xylane, la carboxyméthylcellulose et la cellulose Avicel. La contamination des préparations enzymatiques par des protéines alimentaires a été évaluée. Quel que soit le substrat considéré, l'effet de l'alimentation (heure de prélèvement, ration) sur les activités a été le même pour les 5 traitements. Les activités enzymatiques les plus importantes ont été obtenues avec les traitements faisant intervenir le lysozyme et le $\mathrm{CCl}_{4}$ ou un broyage dans l'azote liquide. La contamination des préparations enzymatiques par des protéines alimentaires a été plus importante avec les traitements chimiques et enzymatiques qu'avec les traitements physiques.

rumen / microorganisme adhérent / activité enzymatique / polysaccharide-dépolymérase

\footnotetext{
* Correspondence and reprints
} 


\section{INTRODUCTION}

Digestion of plant cell walls in the rumen depends on the microbial ecosystem and its activity. Microorganisms that utilise plant structural polysaccharides as their major energy source have to be closely associated with plant particles entering the rumen (Akin, 1979; Chesson and Forsberg, 1988). The microbial population adhering to feed particles is predominant in the rumen (Merry and McAllan, 1983) and is directly responsible for their degradation (Silva et al, 1987). The ability of cell-wall degraders to adhere to plant material is of primary importance and appears an essential first stage in the digestive process (Latham et al, 1979). Adherent fibre-degrading bacteria can help put cell-bound enzymes into contact with the substrate, thereby ensuring effective digestion of cellulosic components (Chesson and Forsberg, 1988). The measurement of particle-bound microbial enzyme activities can be used to predict the rate and extent of fibre degradation in the rumen (Silva et al, 1987). This measurement requires the extraction of these enzymes from microbes adhering to rumen content. Extractions by sonication (Williams and Strachan, 1984; Martin et al, 1993) or lysozyme and carbon tetrachloride $\left(\mathrm{CCl}_{4}\right)$ treatment (Silva et al, 1987; Huhtanen and Khalili, 1992; Bowman and Firkins, 1993) are the most commonly used. However, since this extraction is not complete, the validity of the methods is questionable.

The aim of this experiment was to compare 5 extraction methods, including physical (freezing, grinding, and sonication) and chemical and enzymatic (autolysis in a buffer, lysozyme and $\mathrm{CCl}_{4}$ ) treatments, by studying both extraction yield and variation in response to dietary factors. Extraction yield is of particular importance for measurements of enzymatic activity on crystalline substrates like Avicel cellulose. Hydrolysis of this crystalline substrate requires the activity of a complex cellulasic system, including both exocellobiohydrolases and endo-1,4- $\beta$-D-glucanases, whereas hydrolysis of other more soluble substrates, such as carboxymethylcellulose $(\mathrm{CMC})$, depends mainly on the activity of endo-1,4- $\beta$-D-glucanases. The use of pure Avicel cellulose as a substrate thus provides a situation as close as possible to plant-cellwall cellulose breakdown (Wood and Bhat, 1988). The quantity of enzyme extracted determines the precision of measurements and their relative activities. We have compared, therefore, different extraction methods by studying variations in enzymatic activities with length of time after feeding (Williams et al, 1989) and dietary composition (Huhtanen and Khalili, 1992).

\section{MATERIALS AND METHODS}

\section{Animals and feeding}

Two dry Jersey cows, fitted with ruminal cannula, were fed $(7 \mathrm{~kg} \mathrm{DM} /$ animal/d) with a forage/concentrate diet consisting of hay, straw and barley at ratios of 90:10:0 (cow H) and 30:10:60 (cow $\mathrm{HB}$ ). The animals were fed twice a day at 08.00 and $17.00 \mathrm{~h}$. They also received a mineral/vitamin block and were given free access to water. An adaptation period of 6 weeks was allowed before the measurements were made.

\section{Isolation of solid-associated microbes and enzyme preparation}

Three representative samples of rumen digesta (approximately $300 \mathrm{~g}$ ) were collected via the cannula $2 \mathrm{~h}$ and $23 \mathrm{~h}$ post-feeding, on 3 consecutive days. The samples were collected in a capped bottle to avoid contact with air and immediately transported to the laboratory. They were strained through a 100- $\mu \mathrm{m}$ nylon filter, under a $\mathrm{CO}_{2}$ stream, to separate the solid phase from which the solid-associated microbial enzymes were isolated under anaerobic conditions. The solid-phase 
samples were gently agitated in a bottle with anaerobic salt solution (Coleman, 1978) pre-

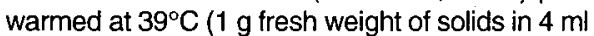
diluent) to remove the non-adherent population associated with particles and were then recovered by filtration $(100 \mu \mathrm{m})$. The surface of the filter was gassed with $\mathrm{CO}_{2}$. The washed digesta solids that contained the adherent population were lacerated under anaerobic conditions and submitted to the 5 following treatments, under the same conditions as described previously by the authors referenced.

In Treatment S, $5 \mathrm{~g}$ (fresh weight) of the solid was suspended in $25 \mathrm{ml}$ pre-cooled $\left(4^{\circ} \mathrm{C}\right)$ anaerobic $(0.025 \mathrm{~mol} / \mathrm{l} 2-(\mathrm{N}$-morpholino) ethane sulphonic acid (MES)) buffer ( $\mathrm{pH}$ 6.5) containing $1 \mathrm{mmol} / /$ dithiothreitol (DTT). The microorganisms present in the suspension were disrupted by ultrasonic disintegration with a Labsonic $U$ ( $B$ Braun) at $4^{\circ} \mathrm{C}$ under anaerobic conditions. Four 30-s periods of sonication with 30-s intervals were used (Williams and Strachan, 1984). Treatment GS was similar to Treatment $S$, but washed digesta solids were ground in liquid nitrogen and the suspension in MES DTT buffer was frozen and thawed before sonication. Treatment $G$ was similar to Treatment GS, except that sonication was not carried out.

In Treatment $L^{+}$and Treatment $L^{-} 2.5 \mathrm{~g}$ (fresh weight) of the solid was incubated under anaerobic conditions at $39^{\circ} \mathrm{C}$ for $3 \mathrm{~h}$ in $25 \mathrm{ml}$ MES DTT buffer with $\left(\mathrm{L}^{+}\right.$, Huhtanen and Khalili, 1992) or without $(L-) 1.25 \mathrm{ml}$ lysozyme $(50 \mathrm{mg} / \mathrm{ml})$ and $3.215 \mathrm{ml} \mathrm{CCl}_{4}$

After treatment, the microbial population was recovered by centrifugation in the same conditions as described previously by the authors referenced: $15000 \mathrm{~g}$ (Treatments $S, G S, G$ ) or $26000 \mathrm{~g}$ (Treatments $\mathrm{L}^{+}, \mathrm{L}^{-}$) for $15 \mathrm{~min}$ at $4^{\circ} \mathrm{C}$. The supernatant fraction was stored under $\mathrm{C}_{2}$ headspace in capped tubes at $-80^{\circ} \mathrm{C}$ until used for enzyme assays. For all treatments, the dry matter (DM) content of samples before suspension in the buffer was determined.

\section{Enzyme assay procedures}

Hydrolysis of xylan (Sigma no X 0502), sodium carboxymethylcellulose (CMC, medium viscosity, Sigma no C 5678) and Avicel (Macherey Nagel, no 81629) were assayed by measuring the amount of reducing sugars formed after incu- bation at $39^{\circ} \mathrm{C}$ for $60 \mathrm{~min}$. The reaction was stopped by heating at $100^{\circ} \mathrm{C}$ for $5 \mathrm{~min}$. The reducing sugars (RS) released were quantified by the p-hydroxybenzoic acid hydrazide method (Lever, 1977) with glucose or xylose as the standard. Xylan $(2 \mathrm{mg} / \mathrm{ml}), \mathrm{CMC}(2 \mathrm{mg} / \mathrm{ml})$ and Avicel $(10 \mathrm{mg} / \mathrm{ml})$ were prepared in MES DTT buffer. Incubation mixtures consisted of either $0.1 \mathrm{ml}$ of enzyme preparation and $1 \mathrm{ml}$ of substrate (CMC and xylan assays) or $0.5 \mathrm{ml}$ of enzyme preparation and $1.5 \mathrm{ml}$ of substrate (Avicel assay). Enzyme and substrate controls were also performed simultaneously by replacing substrate and enzymes by MES DTT buffer, respectively.

The protein content of enzyme preparations was determined by the Pierce method (Pierce and Suelter, 1977) using bovine serum albumin standards. Specific activity was expressed as $\mathrm{nmol} R S$ released per $\mathrm{mg}$ protein in $1 \mathrm{~h}$, and total activity as $\mu \mathrm{mol}$ RS released per $\mathrm{g} \mathrm{DM}$ in $1 \mathrm{~h}$.

\section{Estimation of feed proteins in enzyme preparations}

Eventual presence of feed proteins in enzyme preparations, which would overestimate the extent of extraction ( $\mathrm{mg}$ proteins/g DM), would underestimate specific activities ( $\mathrm{nmol}$ RS released per $\mathrm{mg}$ protein in $1 \mathrm{~h}$ ). In order to estimate this contamination and its influence on the different extraction methods, $12 \mathrm{~g}$ of hay and barley in proportions $100: 0$ and $40: 60$ were incubated at $39^{\circ} \mathrm{C}$ in $1 \mathrm{I}$ of artificial saliva buffer (Vérité and Demarquilly, 1978) under stirring for $2 \mathrm{~h}$. After filtration and washing as described previously, the particles retained on the filter were subjected to the same 5 enzyme extraction methods as the ruminal samples, without taking any anaerobic precautions. Protein concentration was determined by the Pierce method.

\section{Statistical analysis}

Enzyme activities of rumen contents were analysed as a split-plot design using a GLM procedure (SAS Institute, 1985). The activity obtained for each sample was the experimental unit $(n=12$ for each treatment). Feeding (ie combination of diet and sampling time) was the main plot factor and extraction method was the subplot. The main- 
plot error consisted of the replication $x$ feeding interaction. The subplot error $(d f=32)$ was used to test the significance of the extraction method effect and of its interaction with feeding main factor. Extraction method differences were separated by Duncan's multiple range test when the $F$ test was significant $(P<0.05)$.

Protein release in enzyme preparations was analysed with a similar model, with incubation site as the main-plot factor and extraction method as the subplot.

\section{RESULTS}

\section{Enzyme activities}

For the 3 substrates, total (table I) and specific (table II) activities of enzymes extracted by sonication alone (Treatment S) were always lower than activities of enzymes extracted by the other methods.

Xylanase total activity (table I) was significantly higher with grinding treatments (Treatments $G$ and GS) than without grinding (Treatment S) (294 vs $72 \mu \mathrm{mol} R S / g$ $\mathrm{DM} / \mathrm{h})$, and also after action of lysozyme/CCl 4 (Treatment $L^{+}$) compared with action of buffer only (Treatment $L^{-}$) (278 vs $171 \mu \mathrm{mol}$ RS/g DM/h). CMCase total activity was lower after the sonication alone $(5.9 \mu \mathrm{mol} \mathrm{RS} / \mathrm{g} \mathrm{DM} / \mathrm{h})$, and was similar for the other 4 methods $(27.7 \mu \mathrm{mol} \mathrm{RS} / \mathrm{g}$ $\mathrm{DM} / \mathrm{h}$ ). With Avicel, the highest total activities were obtained with grinding or lysozyme $/ \mathrm{CCl}_{4}$ treatments (21.1 and 22.1 $\mu \mathrm{mol} \mathrm{RS} / \mathrm{g} \mathrm{DM} / \mathrm{h}$, respectively). When samples were incubated in the buffer alone, $75 \%$ of the maximal avicelase activity was extracted.

Xylanase specific activity (table II) was higher with grinding treatments than with the sonication alone (8 670 vs $3690 \mathrm{nmol}$ $\mathrm{RS} / \mathrm{mg}$ protein/h), and with lysozyme/CCl 4 (7 $320 \mathrm{nmol} \mathrm{RS} / \mathrm{mg}$ protein/h) than without (5 $760 \mathrm{nmol} \mathrm{RS} / \mathrm{mg}$ protein/h). CMCase specific activity obtained with the sonication alone ( $300 \mathrm{nmol} \mathrm{RS} / \mathrm{mg}$ protein $/ \mathrm{h}$ ) was lower than with the other 4 methods ( $845 \mathrm{nmol}$ $\mathrm{RS} / \mathrm{mg}$ protein/h). A similar trend was observed for avicelase (342 vs $622 \mathrm{nmol}$ RS/mg protein/h).

The mean intra-diet and sampling time variability was the same whatever the extraction method used. The calculated mean variances were $45,4.1$ and 2.8 for xylanase, CMCase and avicelase total activities, respectively, and 1524, 140 and 89 for xylanase, CMCase and avicelase specific activities, respectively.

Table l. Effect of extraction method on total activities of polysaccharide-polymerase enzymes ( $\mu \mathrm{mol}$ reducing sugar/g DM in $1 \mathrm{~h}$ ) in the particle-bound microbial population.

\begin{tabular}{|c|c|c|c|c|c|c|c|c|c|}
\hline \multirow[t]{2}{*}{ Substrate } & \multirow[b]{2}{*}{$S$} & \multicolumn{3}{|c|}{ Extraction method } & \multirow[b]{2}{*}{$L^{-}$} & \multirow[t]{2}{*}{$S E M$} & \multicolumn{3}{|c|}{ Statistical significance } \\
\hline & & $G$ & GS & $L^{+}$ & & & $\begin{array}{l}\text { Extraction } \\
\text { method }\end{array}$ & Feeding & $\begin{array}{l}\text { Extraction } \\
\text { method } x \\
\text { feeding }\end{array}$ \\
\hline Xylan & $72^{c}$ & 291 a & 297 a & $278 a$ & $171^{b}$ & 56 & $\star \star * *$ & $* * *$ & * \\
\hline CMC & $5.9^{b}$ & $28.6^{a}$ & $27.5^{a}$ & $28.8^{a}$ & $26.0^{a}$ & 4.3 & $\star \star \star \star$ & $\star \star \star \star$ & $\star * \star$ \\
\hline Avicel & $6.6^{d}$ & $23.2^{a}$ & $19.0 b c$ & $22.1 a b$ & $17.3^{c}$ & 4.1 & $\star \star \star \star$ & $\star \star \star *$ & $\star$ \\
\hline
\end{tabular}

The values are means of 12 determinations. ${ }^{*} P<0.05 ;{ }^{* *} P<0.001$. a,b,c,d Extraction method significance by $F$ test; means in the same row with different superscripts differ $(P<0.05)$. 
Table II. Effect of extraction method on specific activities of polysaccharide-depolymerase enzymes ( $\mathrm{nmol}$ reducing sugar/mg protein in $1 \mathrm{~h}$ ) in the particle-bound microbial population.

\begin{tabular}{|c|c|c|c|c|c|c|c|c|c|}
\hline \multirow[t]{2}{*}{ Substrate } & \multicolumn{5}{|c|}{ Extraction method } & \multirow[t]{2}{*}{$S E M$} & \multicolumn{3}{|c|}{ Statistical significance } \\
\hline & $S$ & $G$ & GS & $L^{+}$ & $L^{-}$ & & $\begin{array}{l}\text { Extraction } \\
\text { method }\end{array}$ & Feeding & $\begin{array}{c}\text { Extraction } \\
\text { method } x \\
\text { feeding }\end{array}$ \\
\hline Xylan & $3690^{d}$ & $9180^{a}$ & $8160 a b$ & $7320 \mathrm{~b}$ & $5760^{c}$ & 1676 & $\star \star \star$ & $\star \star \star *$ & NS \\
\hline CMC & $300^{c}$ & 897 a & $771^{\circ}$ & $801 a b$ & 909 a & 143 & $\star \star \star \star$ & $\star \star$ & $* * *$ \\
\hline Avicel & $342^{c}$ & $729^{a}$ & $540^{b}$ & $588^{b}$ & $630^{b}$ & 116 & $\star \star \star \star$ & $* *$ & * \\
\hline
\end{tabular}

The values are means of 12 determinations. NS: not significant; * $P<0.05 ;{ }^{* *} P<0.01 ;{ }^{* *} P<0.001$. a,b,c,d. Extraction method significance by $F$ test; means in the same row with different superscripts differ $(P<0.05)$.

\section{Response to feeding}

The responses of the enzymatic activities to feeding, resulting from diet and sampling time, were very important (tables I and II). For all extraction methods, total xylanase and avicelase activities were lower in the cow receiving a mixed forage/concentrate diet (192 and $15.2 \mu \mathrm{mol} R S / g$ DM in $1 \mathrm{~h}$, respectively), compared with the cow fed only forage (251 and $20.0 \mu \mathrm{mol}$ RS/g DM in $1 \mathrm{~h}$, data not shown). In contrast, the total CMCase activity (23.4 $\mu \mathrm{mol}$ RS/ g DM in 1 h) and the specific activities of the 3 enzymes were identical in the 2 cows (6 820, 736 and $566 \mathrm{nmol} \mathrm{RS} / \mathrm{mg}$ protein in $1 \mathrm{~h}$ for xylanase, CMCase and avicelase, respectively, data not shown). A reduction in both total and specific activities was observed after feeding with the 5 methods in the 2 cows. The average decrease was $48 \%$ for xylanase, $56 \%$ for CMCase and $22 \%$ for avicelase (data not shown).

The amplitude of responses to these feeding factors was variable according to extraction method, especially in the case of CMCase $(P<0.001)$. Thus, the decrease in total CMCase activity after feeding appeared to be non-significant when sonication alone was used ( -5.6 units), compared with the other 4 extraction methods $(-21.0$ units in mean).

Therefore, the amplitude of responses to feeding on enzymatic activities was variable according to extraction method, but the trends were the same.

\section{Release of feed proteins in enzyme preparations}

With all the methods, the release of proteins from the rumen contents was, as expected, higher than the release from feed incubated for $2 \mathrm{~h}$ in artificial saliva (table III). The amount of feed proteins extracted from samples incubated in saliva was irrespective of the feed and was higher with enzymatic and chemical $(22.5 \mathrm{mg} / \mathrm{g} \mathrm{DM}$ on average) than with physical treatments (11.7 $\mathrm{mg} / \mathrm{g}$ DM on average). Thus, the proportion of feed proteins in the enzyme preparations from rumen contents would be smaller with these physical treatments, including grinding in liquid nitrogen, with or without sonication. 
Table III. Effect of extraction method on release of proteins in the enzyme preparations after a 2-h incubation period (mg proteins released/g DM).

\begin{tabular}{|c|c|c|c|c|c|c|c|c|c|}
\hline \multirow{2}{*}{$\begin{array}{l}\text { Incubatior } \\
\text { site }\end{array}$} & \multicolumn{5}{|c|}{ Extraction method } & \multirow[t]{2}{*}{ SEM } & \multicolumn{3}{|c|}{ Statistical significance } \\
\hline & $S$ & $G$ & GS & $L^{+}$ & $L^{-}$ & & $\begin{array}{c}\text { Extraction } \\
\text { method }\end{array}$ & $\begin{array}{l}\text { Incubation } \\
\text { site }\end{array}$ & $\begin{array}{l}\text { Extraction } \\
\text { method } x \\
\text { incubation } \\
\text { site }\end{array}$ \\
\hline Buffer & $10.6 \mathrm{Bb}$ & $11.9 \mathrm{Bb}$ & $12.7 \mathrm{Bb}$ & $23.1^{8 a}$ & $21.8 \mathrm{Ba}$ & & & & \\
\hline Rumen & $20.6 \mathrm{Ac}$ & $31.4 \mathrm{Ab}$ & $34.5 \mathrm{Ab}$ & $42.5 \mathrm{Aa}$ & $31.4 \mathrm{Ab}$ & 4.5 & 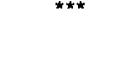 & 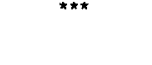 & NS \\
\hline
\end{tabular}

The values are means of 2 (buffer) or 6 (rumen) determinations. NS: not significant; ${ }^{* *} P<0.001$. A.B Incubation site significance by $F$ test; means in the same column with different superscripts differ $(P<0.05)$. a, b. c Extraction method significance by $F$ test; means in the same row with different superscripts differ $(P<0.05)$.

\section{DISCUSSION}

Extraction of microorganism enzymes bound to particles via methods that involve grinding in liquid nitrogen or lysozyme/CCl ${ }_{4}$ gave much higher enzymatic activities than sonication alone. This is true for both specific and total activities. Xylanase and CMCase activities extracted in this experiment by sonication ( 3690 and $300 \mathrm{nmol}$ RS/mg protein $/ h$, respectively) were similar to those reported by Martin et al (1993), obtained under identical feeding, sampling and analytical conditions (3 090 and $310 \mathrm{nmol}$ $\mathrm{RS} / \mathrm{mg}$ protein/h, respectively).

The large quantity of enzymes extracted by Treatment GS appears to result more from grinding and the freezing/defrosting sequence (in comparison with Treatment $S)$ than from the sonication which followed (in comparison with Treatment G). The grinding improves microbial accessibility while freezing/defrosting improves rupture of microbial cells. The Gram-negative bacteria, which are predominant in the rumen, are considered to be particularly susceptible to this treatment (Hammond, 1992).
Lysozyme and $\mathrm{CCl}_{4}$ appeared to have a low specific effect on enzyme extraction, since incubation of digesta in the same buffer alone gave more than $50 \%$ of the activities obtained in the presence of lysozyme and $\mathrm{CCl}_{4}$. In addition to the autolysis of cells suspended in buffer (Treatment $L \rightarrow$, lysozyme hydrolyzed the $\beta-1,4$-glycosidic linkages of peptidoglycanes of bacterial cell walls (Treatment $L^{+}$). It is probable that Gram-positive bacteria, whose peptidoglycane is not protected by an external membrane, are particularly susceptible to this hydrolysis. Possibly $\mathrm{CCl}_{4}$ plays a role in disorganization of bacterial cell walls by its solvent properties.

Few studies have been made to compare techniques for extraction of particlebound microbial polysaccharidases. Silva et al (1987) found no difference between the total microbial CMCase activities extracted by lysozyme/CCl 4 and by sonication. The values obtained by those authors were much higher than those reported here, suggesting that the rates of hydrolysis were measured after shorter incubation periods than in the present trial, but this was not indicated. 
The specific activity of microbial enzymes is expressed in $\mathrm{nmol} \mathrm{RS}$ released/mg proteins in $1 \mathrm{~h}$. These proteins present in the enzymatic preparations are of both microbial and dietary origin. Extraction methods may break down both bacterial and plant cells. To estimate this possible contamination of enzymatic preparations by dietary proteins, feed samples identical to those given to the animals were incubated in artificial saliva and then subjected to the same extraction treatments as the digestas. This method overestimates the importance of dietary proteins in enzymatic preparations since only the soluble protein fraction in the buffer is eliminated before extraction. Thus, the results obtained have only a relative value permitting comparison between extraction methods. The quantities of feed proteins extracted were smaller with physical treatments (freezing, grinding and/or sonication) than with enzymatic and chemical treatments (buffer with or without lysozyme $\left./ \mathrm{CCl}_{4}\right)$. The proportion of dietary proteins in enzyme preparations would appear to be smaller with treatments involving grinding and freezing compared with enzymatic and chemical treatments or sonication only.

Differences in activities of particle-bound microbial enzymes observed between the 2 diets were in agreement with those reported in literature: diminution of total CMCase and xylanase activities due to starch or sugar supplements (Silva et al, 1987; Huhtanen and Khalili, 1992); and diminution of activities after feeding (Williams et al, 1989; Bowman and Firkins, 1993; Martin et al, 1993). In this trial, differences in activities observed between the 2 cows could not be entirely explained by a diet effect, each cow receiving only one diet. However, the 5 extraction methods gave the same responses to feeding. The amplitude of responses were different and, notably were lower when sonication alone was used.
The extraction methods compared in this experiment thus gave the same responses to feeding. Grinding in liquid nitrogen improved enzyme yield, in terms of activity, compared with sonication alone. The enzymatic and chemical treatments extracted identical quantities of enzymes as grinding, but they also liberated more feed proteins, which means that specific enzyme activity is underestimated.

\section{ACKNOWLEDGMENTS}

This research was supported by UCAAB $50 \%$. We wish to thank $L$ Genestoux for her technical assistance, and $\mathrm{E}$ Forano for valuable advice.

\section{REFERENCES}

Akin DE (1979) Microscopic evaluation of forage digestion by rumen microorganisms-a review. J Anim Sci 48, 701-710

Bowman JGP, Firkins JL (1993) Effects of forage species and particle size on bacterial cellulolytic activity and colonization in situ. J Anim Sci 71, 1623-1633

Chesson A, Forsberg CW (1988) Polysaccharide degradation by rumen microorganisms. In: The Rumen Microbial Ecosystem (PN Hobson, ed) Elsevier Appl Sci, London, 251-284

Coleman GS (1978) Rumen entodiniomorphid protozoa In: Methods of Cultivating Parasites In Vitro (AER Taylor, JR Baker, eds) Academic Press, London, 39-54

Hammond PM (1992) Protein purification. In: Encyclopedia of Microbiology (J Lederberg, ed) Academic Press Inc, San Diego, vol 3, 451-460

Huhtanen $P$, Khalili $H$ (1992) The effect of sucrose supplements on particle-associated carboxymethylcellulase $(E C 3.2 .1 .4)$ and xylanase (EC 3.2.1.8) activities in cattle given grass-silage-based diet. Br $J$ Nutr $67,245-255$

Latham MJ, Hobbs DG, Harris PJ (1979) Adhesion of rumen bacteria to alkali-treated plant stems. Ann Rech Vet 10, 244-245

Lever M (1977) Carbohydrate determination with 4hydroxybenzoic acid hydrazide (PAHßAH): effect of bismuth on the reaction. Anal Biochem 81, 21-27

Martin C, Michalet-Doreau B, Fonty G, Williams A (1993) Postprandial variations in the activity of polysaccharide-degrading enzymes of fluid- and particle- 
associated ruminal microbial populations. Curr Microbiol 27, 223-228

Merry RJ, McAllan AB (1983) A comparison of the chemical composition of mixed bacteria harvested from the liquid and solid fractions of rumen digesta. $\mathrm{Br} \mathrm{J}$ Nutr 50, 701-709

Pierce J, Suelter $\mathrm{CH}$ (1977) An evaluation of the Coomassie brilliant blue G-250 dye-binding method for quantitative protein determination. Anal Biochem $81,478-480$

SAS Institute (1985) SAS User's Guide: Statistics. SAS Institute, Inc, Cary NC

Silva AT, Wallace RJ, Orskov ER (1987) Use of particlebound microbial enzyme activity to predict the rate and extent of fibre degradation in the rumen. $\mathrm{Br} J$ Nutr 57, 407-415
Vérité R, Demarquilly C (1978) Qualité des matières azotées des aliments pour ruminants. In: La Vache Laitière (INRA Publ, ed) INRA, Versailles, France, 143-157

Williams AG, Strachan NH (1984) The distribution of polysaccharide-degrading enzymes in the bovine rumen digesta ecosystem. Curr Microbiol 10, 215220

Williams AG, Withers SE, Strachan NH, (1989) Postprandial variations in the activity of polysaccharidedegrading enzymes in microbial populations from the digesta solids and liquor fractions of rumen contents. J App/ Bacterio/ 66, 15-26

Wood TM, Bhat KM (1988) Methods for measuring cellulase activities. Methods Enzymol 160, 87-112 